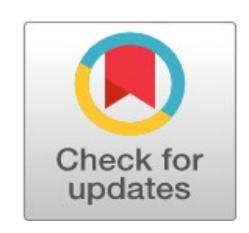

\title{
Sociological analysis on prisoners; with special reference to prisoners of death penalty and life imprisonment in Sri Lanka
}

\author{
Wasantha Subasinghe ${ }^{1, *}$ \\ ${ }^{1}$ Department of Sociology, University of Kelaniya, Sri Lanka
}

\author{
Keywords: \\ Death penalty \\ Expectations \\ Life imprisonment \\ Rehabilitation
}

Received: 3 December 2015

Accepted: 20 January 2016

Published: 22 February 2016

\begin{abstract}
This research paper tried to analyze the ideas on the death penalty and life imprisonment experiences of its offender's perspective. Within the framework of giving punishments and control, criminals are essential for society to its best functioning. There are organized crimes and instantaneous crimes against humans and property. Findings revealed causes for engaging in criminal behavior as well as feelings of them as offenders. The death penalty and life imprisonment have been punished, especially for drug selling and murders. The end of life imprisonment is decided by nature, but the president of Sri Lanka will decide the death penalty in the Sri Lankan context. Still, there is no decision on implementing the death penalty in Sri Lanka. Both categories of prisoners need if implementing the death penalty or freedom. Some of them need to convert death sentences to life imprisonment. They are physically and mentally damaged after their imprisonment. Lack of hope and lack of welfare and rehabilitation programs they suffered their lives in the prison. The findings of this study will be helpful for the government and policymakers.
\end{abstract}

(C) 2016 The Author(s). Published by TAF Publishing.

\section{INTRODUCTION}

Crimes are becoming a one of burning issues in Sri Lanka. Crime is mean by someone brakes the rules in a certain society. A person who violates a law is called to have committed a criminal offense. There are two main categories of crime as property crime and violent crime. A property crime is call as when someone damages, destroys or steals someone else's property. It means crime behavior against property. For example such as stealing, destroy buildings, burning permanent and mobile things such as vehicles, schools, houses etc. A violent crime means when someone harms, attempts to harm, threatens to harm or even conspires to harm someone else. Violent crimes are offenses which involve force or threat of force, such as rape, robbery or homicide. Crime

\footnotetext{
* Corresponding author: Wasantha Subasinghe

E-mail: rovelinajacolbia@yahoo.com
} 
is defined as "An action or an instance of negligence that is deemed injurious to the public welfare or morals or to the interests of the state and that is legally prohibited" (Dictionary.com). On the other hand crimes can be considered as offences in minor crimes and grave crimes including murder, rape, trafficking, robbery, excise, narcotic, kidnapping and so on. According to the literature "a crime is an offence against the public law. It is an act committed or omitted in violation of a law forbidding or commanding it and for which punishment is imposed upon conviction. Crimes violate the law and order of a society and it negatively affects the social structure and the society's fundamental values, morale and belief system" (Jayathunga, 2011). Crime is a big problem in rural as well as urban areas in Sri Lanka.

Reported crime rate are becoming high in Sri Lanka. When describing below mentioned table it can be proved.

TABLE I. Grave crime abstract for the year 2014

\begin{tabular}{|c|c|}
\hline Crime & Cases Recorded \\
\hline Abduction/Kidnapping & 1036 \\
\hline Arson & 578 \\
\hline Mischief over Rs. $5000 /=$ & 1194 \\
\hline House Breaking \& Theft & 15050 \\
\hline Grievous Hurt & 1402 \\
\hline Hurt by Knife etc & 2635 \\
\hline Homicide/Abetment to commit suicide & 548 \\
\hline Attempted Homicide & 188 \\
\hline Rape/Incest & 2008 \\
\hline Riots & 11 \\
\hline Robbery & 4235 \\
\hline Unnatural Offense/Grave & 560 \\
\hline sexual abuse & 135 \\
\hline Extortions & \\
\hline Cheating/ Misappropriation C.B. trust over Rs. 100,000/ & 8651 \\
\hline $\begin{array}{l}\text { Theft of property including praedial produce over Rs. 5,000 \& Cycle } \\
\& \text { Cattle thefts irrespective of their value. }\end{array}$ & 10980 \\
\hline Counterfeiting Currency & 52 \\
\hline Offence against the state & 0 \\
\hline Cruelty to children \& sexual exploitation of children & 377 \\
\hline
\end{tabular}

Source: Sri Lanka Police Data, 2014

Punishment is a reply which is given by the society to person who has done anty-social behavior. It occurs through law and customs. Costoms were ruled basically in traditional society for control social behavior. Now it is doing by the Law. "A penalty imposed on a defendant duly convicted of a crime by an authorized court. The punishment is declared in the sentence of the court. The two basic principles governing punishment are nullum crimen sine lege (no crime without a law) and nulla poena sine lege (no punishment without a law." (Talagala, 2012). The purpose of punishment is preventing crimes and giving a punishment to broken rules. According to scholars who wrote on punishment 
are four factors as retribution, deterrence, incapacitation and reformations (Thalagala, 2012). There are major classifications of civil codes as follows.

i. The Civil Code.

ii. The Code of Civil Procedure: Civil Procedure Code. Act 79 of 1988. Amended by Acts 9 of 1991 and 34 of 2000.

iii. Commercial Code.

iv. Criminal Code: Penal Code. Chapter 25. Amended by Penal Code (amendment) Act of 1995.

v. Code of Criminal Procedure: Code of Criminal Procedure Act. Chapter 26, Law 15 of 1979. Amended by no. 39 of 1982 (The 1979 Act repealed earlier codifications) Tambimuttu, 2009).

Hamurabi law is one of famous traditional punishment systems in the world. In Sri Lankan context, there was a traditional punishment system called "Dethis wadaya" (32 punishment). It was decided by the king or an authorized person. It included with different kinds of punishments to relevant crimes. As an overall idea on traditional punishment is, there were physical punishments, mental punishments, verbal punishments and financial punishments also. For an example; some of physical punishments were flaying, boiled alive, locking by the wood, handing, boiling by oil, burning etc. After the independence, the government rules have been changed. Instead of traditional punishment systems new court system was introduced. In the present situation punishments for crimes are totally decided by the courts. There are various forms of punishment such as bailing, fining, and prisoning for several years, life imprisonment and death penalty.

Death penalty or capital punishment means that punishment by death. There were different kinds of methods for implementing death penalty as historically. Some of them were done using animals such as crushing by elephant, burning, buried alive, boiling to death, falling, shooting, keeping starvation and dehydration and so on. Most common methods for execution are hanging and using electronic chair in the present.

According to the history of criminal justice system in Sri Lanka, it has benchmark time periods as period before the European powers occupied the island (before 1505 A.D), period during the Portuguese occupation (15051656), period during the Dutch occupation (1656-1796) period during the British occupation (1796-1947), and post-independence period (1948 to date) (Niriella, 2013). Death penalty has a long history from traditional feudal kingdoms or kings' ruling time in Sri Lanka. It was practiced as a king's order. It was stopped in the British colonial period. Currently death penalty is governed by the penal code getting from the British jurisprudence. But after independence, Prime Minister S. W. R. D. Bandaranaike abolished capital punishment in 1956. But that decision was suddenly changed due to his assassination. Death penalty was reintroduced in 1959. Death penalty is legal in Sri Lanka. It is mainly doing by hanging. But there have been no implementations since 23 June 1976. The government decided to reinstate capital punishment in 2004 for cases of rape, drug trafficking and murder. Over the last decades, several presidents as Mrs.Chandrika Kumaratunga tried to implements or re-introduce the death penalty again. But still it is in only a court 
order. According to the constitution, after the court order on death penalty, the president must give a date for the death penalty.

TABLE 2. Countries which are legally banded the death penalty

\begin{tabular}{|c|c|c|c|}
\hline Country & Year of banned & Country & Year of banned \\
\hline Andorra & 1990 & Marshall Islands & 1986 \\
\hline Angola & 1992 & Mauritius & 1995 \\
\hline Armenia & 2003 & Mexico & 2005 \\
\hline Australia & 1984 & Micronesia & 1986 \\
\hline Austria & 1950 & Moldova & 1995 \\
\hline Azerbaijan & 1998 & Monaco & 1962 \\
\hline Belgium & 1996 & Mozambique & 1990 \\
\hline Bermuda & 1999 & Namibia & 1990 \\
\hline Bhutan & 2004 & Nepal & 1990 \\
\hline Bosnia-Herzegovina & 1997 & Netherlands & 1870 \\
\hline Bulgaria & 1998 & New Zealand & 1961 \\
\hline Cambodia & 1989 & Nicaragua & 1979 \\
\hline Canada & 1976 & Niue & (n.a.) \\
\hline Cape Verde & 1981 & Norway & 1905 \\
\hline Colombia & 1910 & Palau & (n.a.) \\
\hline Costa Rica & 1877 & Panama & 1903 \\
\hline Côte d'Ivoire & 2000 & Paraguay & 1992 \\
\hline Croatia & 1990 & Poland & 1997 \\
\hline Cyprus & 1983 & Portugal & 1867 \\
\hline Czech Republic & 1990 & Romania & 1989 \\
\hline Denmark & 1933 & Samoa & 2004 \\
\hline Djibouti & 1995 & San Marino & 1848 \\
\hline Dominican Republic & 1966 & São Tomé and Príncipe & 1990 \\
\hline East Timor & 1999 & Senegal & 2004 \\
\hline Ecuador & 1906 & Serbia and Montenegro & 2002 \\
\hline Estonia & 1998 & Seychelles & 1993 \\
\hline Finland & 1949 & Slovak Republic & 1990 \\
\hline France & 1981 & Slovenia & 1989 \\
\hline Georgia & 1997 & Solomon Islands & 1966 \\
\hline Germany & 1987 & South Africa & 1995 \\
\hline Greece & 1993 & Spain & 1978 \\
\hline Guinea-Bissau & 1993 & Sweden & 1921 \\
\hline Haiti & 1987 & Switzerland & 1942 \\
\hline Honduras & 1956 & Turkey & 2002 \\
\hline Hungary & 1990 & Turkmenistan & 1999 \\
\hline Iceland & 1928 & Tuvalu & 1978 \\
\hline Ireland & 1990 & Ukraine & 1999 \\
\hline Italy & 1947 & United Kingdom & 1973 \\
\hline Kiribati & 1979 & Uruguay & 1907 \\
\hline Liberia & 2005 & Vanuatu & 1980 \\
\hline Liechtenstein & 1987 & Vatican City & 1969 \\
\hline Lithuania & 1998 & Venezuela & 1863 \\
\hline Luxembourg & 1979 & Malta & 1971 \\
\hline Macedonia & 1991 & & \\
\hline
\end{tabular}


According to the Commissioner of the Human Rights Commission of Sri Lanka (HRCSL) mentioned that HRCSL will propose to the government that death sentences imposed on convicts be converted to life imprisonment, according to a report in The Nation 2014.

There are three types of way which death penalty is appearing today worldwide. These are,

1. Legally banded countries

2. No longer execute but have no legal ban

3. Legally accepted and implementing

The discourse of death penalty is endless. According to the Buddhism all living being has a same right to live, No one can't violate it. It is directly influence to Sri Lankan context to take a decision to implementing death penalty. On the other hand there should be a study on understanding the relationship between death penalty and crime deterrence.

TABLE 3. Countries no longer execute people, but have no legal ban

\begin{tabular}{lclc}
\hline \hline Country & Stopping year & Country & Stopping year \\
\hline Albania & 2000 & Gambia & 1981 \\
Argentina & 1984 & Grenada & 1978 \\
Bolivia & 1997 & Kenya & (n.a.) \\
Brazil & 1979 & Madagascar & 1958 \\
Chile & 2001 & Maldives & 1952 \\
Cook Islands & (n.a.) & Mali & 1980 \\
El Salvador & 1983 & Mauritania & 1987 \\
Fiji & 1979 & Morocco & 1993 \\
Israel & 1954 & Myanmar & 1993 \\
Latvia & 1999 & Nauru & 1968 \\
Peru & 1979 & Niger & 1976 \\
Algeria & 1993 & Papua New Guinea & 1950 \\
Benin & 1987 & Russia & 1999 \\
Brunei Darussalam & 1957 & Sri Lanka & 1976 \\
Burkina Faso & 1988 & Suriname & 1982 \\
Central African Republic & 1981 & Togo & (n.a.) \\
Congo (Republic) & 1982 & Tonga & 1982 \\
& & Tunisia & 1990 \\
\hline \hline
\end{tabular}

The prison department is the legally authorized for keeping prisoners and implementing punishments and conduct rehabilitation programs for offenders in Sri Lanka. There are 23 prison institutions in Sri Lanka including 03 closed prisoners and 20 remand prisons. There are 10 work camps, 02 open prison camps, 01 training school for youth offenders and 02 correctional centers for youth offenders.

As earlier mentioned, capital punishment is legal in Sri Lanka as many other countries as India, Japan, Bangladesh, Iran and Iraq so on. When compared unconvicted prisoners from 2006-2010 there is an increase. It was 89190 in 2006 and it was 100191 in 2010 . There were 28732 of convicted prisoners and 
it was 32128 in 2010 . There were 165 Death sentences in 2006 and it was 96 in 2010. There are 540 individuals had been sentenced to death (Prison Statistics).

TABLE 4. Countries are capital punishment is still legal

\begin{tabular}{|c|c|c|c|}
\hline \multicolumn{4}{|c|}{ Country name } \\
\hline Afghanistan & Egypt & Kyrgyzstan & Somalia \\
\hline Antigua and Barbuda & Equatorial Guinea & Laos Libya & Sudan \\
\hline Bahamas & Eritrea & Malawi & Swaziland \\
\hline Bahrain & Ethiopia & Malaysia & Syria \\
\hline Bangladesh & Gabon & Mongolia & Taiwan \\
\hline Barbados & Ghana & Nigeria & Tajikistan \\
\hline Belarus & Guatemala & Oman & Tanzania \\
\hline Belize & Guinea & Pakistan & Thailand \\
\hline Botswana & Guyana & Palestinian Authority & Trinidad and Tobago \\
\hline Burundi & India & Philippines & Uganda \\
\hline Cameroon & Indonesia & Qatar & United Arab Emirates \\
\hline Chad & Iran & Rwanda & United States \\
\hline China (People's Republic) & Iraq & St. Kitts and Nevis & Uzbekistan \\
\hline Comoros & Jamaica & St. Lucia & Vietnam \\
\hline Congo (Democratic & Japan & St. Vincent and the & Yemen \\
\hline Republic) & Jordan & Grenadines & Zambia \\
\hline Cuba & Kazakhstan & Saudi Arabia & Zimbabwe \\
\hline \multirow[t]{4}{*}{ Dominica } & Korea, North & Sierra Leone & \\
\hline & Korea, South & Singapore & \\
\hline & Lebanon Lesotho & & \\
\hline & Kuwait & & \\
\hline
\end{tabular}

\section{LITERATURE REVIEW}

Talagala (2012) has mentioned in his research on "Implementing Capital Punishment in Sri Lanka: Some Views and Jurisprudential Thoughts" on different stakeholders' view on implementing capital punishment. The senior academic objecting to the implementation of capital punishment said, killing is an immoral and unethical act whether it is done by an individual or the State. Life is precious to all human beings and the capital punishment violates the right to life. According to Buddhist philosophy it is not accepted. Buddhism recognized physical punishment to balance to offence committed. Capital punishment aims to satisfy two basic objectives of punishment, i.e. retribution and deterrence. It is generally accepted that punishment should be proportionate to the crime committed.

Niriella (2013) revealed the justice system in Sri Lanka on his article on "The emergence of restorative justice in Sri Lanka: a review essay". According to him Sri Lanka adopts methods in the justice system are victim offender mediation, restitution, probation, conditional discharge, suspended sentencing and community based correction. Although, the programs relating to ex-offender assistance are not institutionalized. In his conclusion, he mentioned that the attitude of the public toward punishment is still influenced by traditional retributive thoughts where the offender should be treated harshly with severe punishment through punitive approach. 
Jones and Richard (2011) exposed the relationship between mortality salience and death penalty. Their article on "Effects of mortality salience on capital punishment sentencing decision" has tested Terror Management Theory (TMT) and the possibility of escape mortality salience effects. TMT imagines that the awareness of one's own death (mortality salience) influences cognitive functioning and behavioral reactions. It has cultural and psychological values. In the conclusion, participants relied on their attitudes to make sentencing decisions when focusing on the death of victim and possible death of the defendant compared to when they focused on their own mortality. Auerbanch (2001) discussed the differences between USA and Britain way of thinking on death penalty through their article on "The dividing line on capital punishment". These two countries share a common history, common language and political and economic associates. There are three major components on capital punishment. These are domestic in nature, public and political support and international pressure. The combination of public and political support, along with international pressure, had a direct impact on the decisions of its nations.

Lamperiti (1994) researched on the connection with murder deterrence and capital punishment. The research article on "Does capital punishment deter murder?" revealed overwhelming majority among America's leading criminologist who believe that capital punishment does not contribute to lower rates of homicides. Schweizer (2013) has shown the effects of capital punishment on their family on "Racial disparity in capital punishment and its impact on family members of capital defendants". It's focused on family members of African American defendants. The family members are unseen as they are shunned by the community due to their relationship to the defendant. They needs for information, assistance, and emotional support. The resources available to the often limited or nonexistent. They need counseling and other external support.

Gupta (2014) has done a comparative study on death penalty. The article titled on "Capital punishment: a comparative study between India and China" focused on death penalty stands globally. China gives death penalty for 55 offences but chines law excluded from death penalty are minors, pregnant woman, elderly and mentally ill people.

\section{RESEARCH METHODOLOGY}

Research problem: What are the main causes for receiving capital punishment and life imprisonment in Sri Lanka?

\section{Research Question}

What are the feelings of prisoners as waiting for death?

\section{Objectives}

Objectives of the study were identifying prisoners' point of view on their punishment and root causes for their offence.

\section{Data Collecting Method and Techniques}

This was a basic research. Case studies were conducted to identify the research problem and data were collected using formal interviews. Research area was 
Welikada prison. Stratified sampling method in probability samplings was used. Sample size was 20 cases from death penalty and life imprisonment prisoners and 20 from other convicted prisoners.

\section{DISCUSSION \\ Back Ground of Participants}

Participants were 20 males who are punished for death penalty and life imprisonment. They were selected form "Welikada' prison which the prison is allocated for prisoners who come for the first time as an offender. All the case studies were done by the correspondent researcher using by formal semi structured interviews. There were two stages of this basic research selecting the sample. The study has focused to getting surface understanding on prisoners according to their offence in the first stage. Therefore, the first sample was randomly selected. Thus, real sample was the purposively selected one which was with death penalty and life imprisonment prisoners.

The study concentrated to get basic background details on prisoners on ethnicity, religion, age and educational level. When considering the ethnicity Sri Lanka has four main ethnicities as Sinhala, Tamil, Muslims and Burgers as national level. Sinhalese are $74 \%$ and Muslims are $9 \%$ in its in national contribution. According to field data, it was $95 \%$ of Sinhalese and 5\% was Muslims. There were no any other ethnics as Tamils and Burgers in the sample.
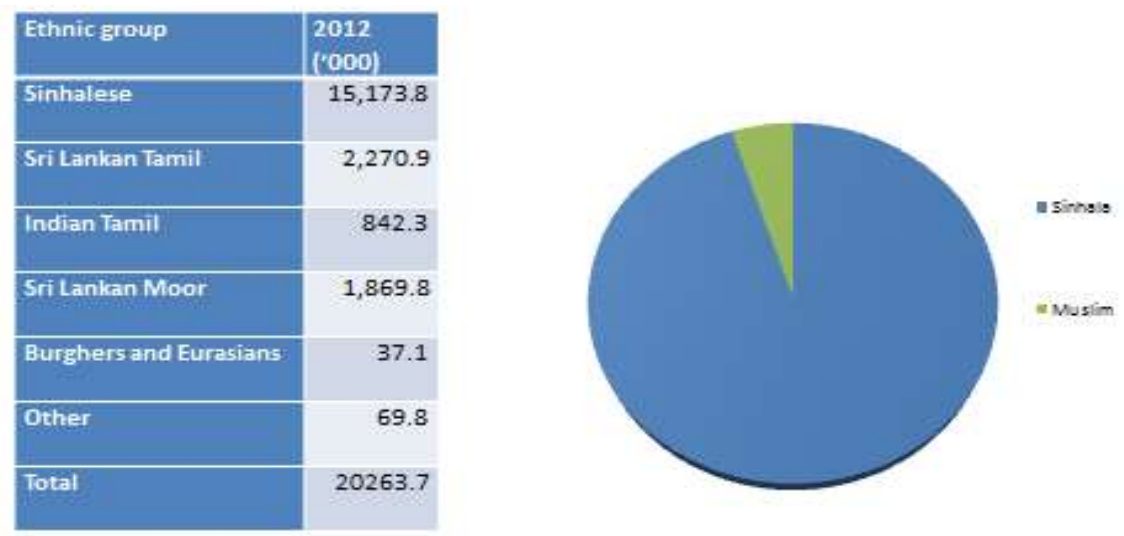

Source: Department of sensus and statistics 2012 and field data 2015

FIGURE 1. Population by ethinic group

The religious categories in Sri Lanka are Buddhists, Hindus, Islamic and Catholics. Buddhist representation is $70 \%$, Islamic are $9.5 \%$, Hindus are $12.5 \%$ and Catholics are $7 \%$ in national level population rates. There were no Hindus and Catholics in the sample. It can be summarized as bellows. 

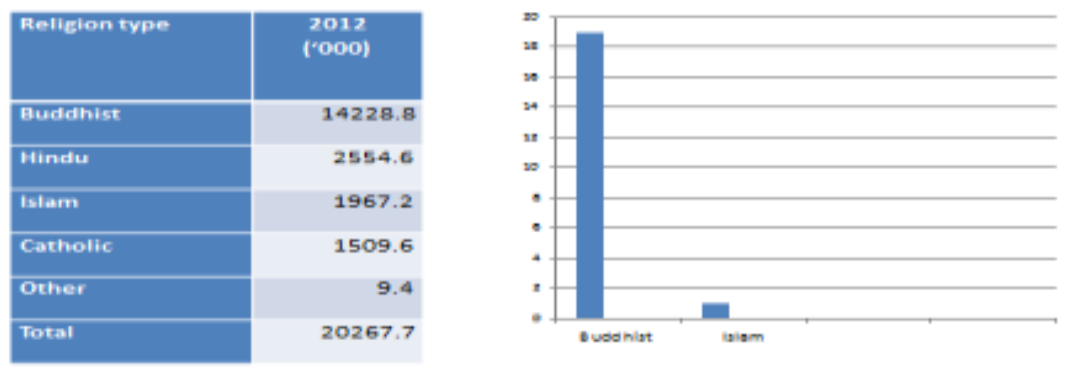

Source: Department of sensus and statistics 2012 and field data 2015

FIGURE 2. Population by Religion

\begin{tabular}{|l|l|l|l|}
\hline Year & $\begin{array}{l}\text { Age } \\
\text { group } \\
01-14 \\
(1000)\end{array}$ & $\begin{array}{l}\text { Age } \\
\text { group } \\
15-59 \\
(1000)\end{array}$ & $\begin{array}{l}\text { Age } \\
\text { group } \\
60> \\
(1000)\end{array}$ \\
\hline 2012 & 5229 & 12566 & 2468 \\
\hline
\end{tabular}

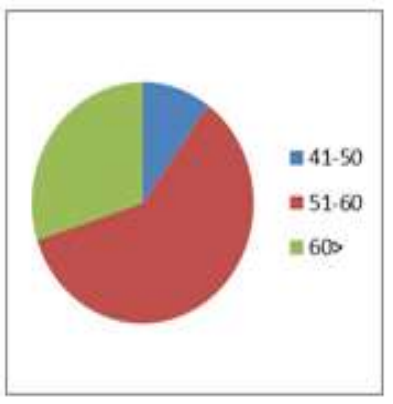

Source: Department of sensus and statistics 2012 and field data 2015

FIGURE 3. Population by age group

Age between 51-60 years was representing $60 \%$. There was $30 \%$ representation between age group of 60 over. $25 \%$ of them are already spent more than 15 years in the prison. Generally mean of entry to the prison is in age of about 50 .

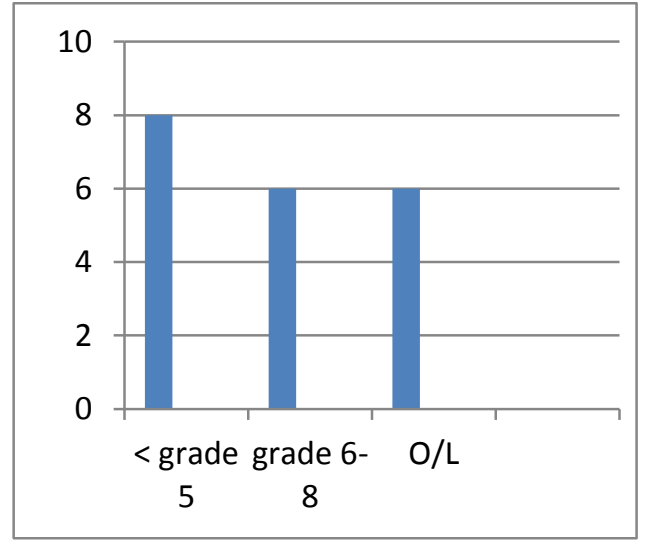

Source: Field data 2015

FIGURE 4. Educational level of respondents

Educational level of respondents was significant. There was no anyone who leant above grade ten. $40 \%$ representatives were leant to grade five. $30 \%$ for 
below grade eight and 30\% below grade ten and its representation. All were come from rural areas. There is no one from Colombo district from the sample. Among them $45 \%$ were reported from Southern province and $20 \%$ reported from Sabaragamuwa province. There was a new trend that murder cases increase in Sabaragamuwa province last few years especially in Rathnapura district.

Past few decades gives evidence that Sri Lanka has a big history on war and violence. Physical war was finished in 2009. But violence against human being, property and nature is still occurring. Violence and aggression can be seen as different types as violence against personal, violence in institution and social violence.

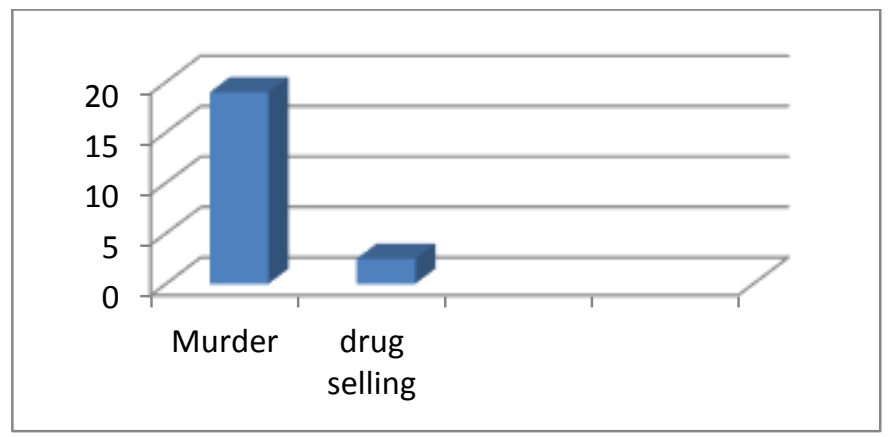

Source: Field data 2015

FIGURE 3. Category by offence

Categorize offences are in deferent point of view. According to the prison department there are five types of offences as criminal offences against persons, offences against property, offences against public tranquility state law and order, and other offence and child abuse. Criminal offences against persons are offences such as murder, drugs, culpable homicides, attempted murder, attempted culpable homicides, kidnapping, rape, grievous hurt, simple hurt, bigamy, unnatural offences, concealment of birth, criminal force, and criminal intimidation etc. Death penalty is sentenced for murder, drug selling and attempted murder according to penal code of Sri Lanka. Life imprisonment is sentenced for kidnapping, robbery, rape and smuggling on considering its weight.

Out of hundred $95 \%$ of offenders were convicted for murdering. The reasons for murdering were land matters, unlawful love affairs, fighting, and financial matters so on. Among them 2 of them murdered their wives. Most of them suffered. According to them it was manageable behavior but they could not do it. $60 \%$ of offenders were farmers on paddy and Chena cultivation. $60 \%$ of them were businessmen and some of them engaged with illegal drug selling and selling meat. 


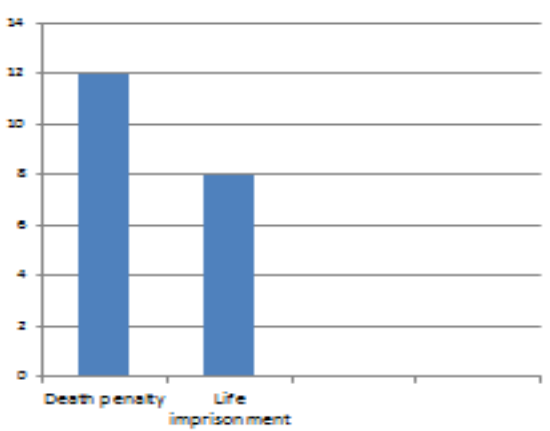

Source: Field data 2015

\begin{tabular}{|l|c|c|}
\hline Type & \multicolumn{2}{|c|}{ Spent Years } \\
\hline & amount & $\%$ \\
\hline$<1$ years & 02 & 10 \\
\hline $2-5$ years & 02 & 10 \\
\hline $6-10$ years & 07 & 35 \\
\hline $11-15$ years & 04 & 20 \\
\hline $16-20$ years & 05 & 25 \\
\hline Total & 20 & 100 \\
\hline
\end{tabular}

FIGURE 3. Attitude towards death penalty and life imprisonment

In their point of view; living with the decision of life imprisonment and death penalty is too difficult and tough. Out of hundred $60 \%$ of were expecting their death penalty. Others were living for life imprisonment. 55\% of them already spent more than six years in the prison. If, they were real offenders or not, some of them appealed their cases. According to them (death penalty offenders) they are expecting replacement such as instead of death penalty they need life imprisonment. Offenders who were punished for life imprisonment need to less their prisonment. On the other hand $25 \%$ they have more than 15 years in prison. They are engaging with deferent kinds of activities as weaving works, bakery works, coir works, laundry works, tailoring and cleaning service for getting financial support. Some works are doing for their day to day existence such as cooking, cleaning, farming, office works, religious works etc. In addition, there are counseling programs, arms giving programs, health programs, and cultural activities.

Interviews with offenders have conducted to explore how the have been impacted by the death penalty. Most of them satisfied with their day to day life. Some of them questioned about the rehabilitation programe. More than $75 \%$ offenders need their death penalty. They suffered their living because they are waiting for their death. The president should decide to implement the punishment according to Sri Lankan death penalty law. Presidents who became as a president in Sri Lanka after 1976, did not sign for the implementing the death penalty. There is a discourse on implementing death penalty since its stopping.

\section{CONCLUSION AND RECOMMENDATIONS}

The study focused to understand prisoners' point of view on their imprisonment. Prisoners who are expecting theirs' death penalty; they have two demands as first one is that if there is a chance to convert their death penalty to life imprisonment is very appreciated. But if there is no chance to do it, necessary action they needed is implementing their death penalty. These two demands are under the authority of the president of Sri Lanka.

The prisoners who have life imprisonment need to convert it to the imprisonment for considerable certain years. This demand also happens under the recommended of the president of Sri Lanka. 
In the conclusion, it is argued that there should be a big discourse on implementing death penalty in Sri Lanka. Experts of different fields as criminology, psychology, religious, law and order must make a round table discussion on it. There should be a public opinion on implementing or banned death penalty.

\section{REFERENCES}

Akpalu, Wisdom, Wisdom Akpalu, and Anatu Mohammed. 2013. Socioeconomics of crime and discretionary punishment: The case of Ghana.International Journal of Social Economics 40, no. 2: 116-126. DoI: 10.1108/03068291311283599

Auerbanch, Arthur H. 2001. The dividing line on capital punishment. Peace Review 13, no. 4: 545-551. D0I: $10.1080 / 10402650120100927$

Department of Census and Statistics. 2012. Census of Population and Housing2012. Ministry of Finance and Planning, Sri Lanka.

Dias, Wije. 2004. Sri Lankan president moves to reinstate the death penalty. World socialist wed site. URL: https://www.wsws.org/en/articles/2004/11/sri-n26.html (accessed March 28, 2016).

Gupta, Nikita. 2014. Capital punishment: A comparative study between India and China. Final Project, Gujarat national law university, India.

Jayathunga, N. S. 2010. A sociological study of the Homicide in Sri Lanka: A case study in Rathnapura secretariat division. Sabaragamuwa University Journal 9, no. 1: 45-55.

Jayathunga, Ruwan M. 2011. Sociological aspect of crime.

Jonesa, Megan B., and Richard L. Wiener. 2011. Effects of mortality salience on capital punishment sentencing decisions. Basic and Applied Social Psychology 33, no. 2: 167-181. D0I: 10.1080/01973533.2011.568852 Lamperti, John. 1994. Does capital punishment deter murder. Journal of Social Issues 50, no 2: 1-18.

Niriella, M.A.D.S.J.S. 2013. The emergence of restorative justice in Sri Lanka: A review essay. International Journal of Comparative and Applied Criminal Justice 37, no. 3: 233-247. D0I: 10.1080/14791420.2012.734441

Schweizer, Jennifer. 2013. Racial disparity in capital punishment and its impact on family members of capital defendants. Journal of Evidence-Based Social Work, 10, no. 2: 91-99. DOI: 10.1080/15433714.2011.581549

Talagala, Chamila S. 2012. Implementing Capital Punishment in Sri Lanka: Some Views and Jurisprudential Thoughts.S

Tambimuttu, Aquinas V. 2009. Sri Lanka: Legal research and legal system. URL: http://goo.gl/2v0VRT (accessed 29, 2016).

— This article does not have any appendix. - 